\title{
REPRODUÇÃO BIOLÓGICA E CLASSES SOCIAIS
}

Rosa Maria Godoy Serpa da Fonseca*

FONSECA, R.M.G.S. da. Reproduç̧o biológica e classes sociais. Nota prévia. Rev. Esc. Enf. USP, Såo Paulo, 22(2):251-252, ago. 1988.

\section{NOTA PRÉVIA}

A concepção idealista dos programas de assitência à saúde da mulher, que ignora a determinação social da reprodução biológica, dá aos fatos uma explicação baseada em modelos que, ao invés de chegar às verdadeiras causas dos problemas, coloca uma cortina ideológica que distorce a realidade e, portanto, oferece soluçðes que permitem apenas obter os resultados pragmáticos adequados, sem tocar as verdadeiras causas estruturais que podem desequilibrar o sistema.

Em vista disso, pretende-se desenvolver uma pesquisa com os objetivos de conhecer e explicar o perfil reprodutivo biológico, segundo a inserção da população selecionada em classes sociais, admitindo-se que para cada classe social existe um perfil reprodutivo próprio, determinado socialmente, pelas formas peculiares de produzir e consumir de cada classe social.

A análise dos dados através do referencial do materialismo histórico e dialético, admite-se, permite a explicaçăo científica dos fatos biológicos, entre os quais, o da reprodução biológica.

O estudo tem a finalidade de obter subsidios para a transformação qualitativa e quantitativa dos programas de saúde da mulher numa base real, condizente com a situação peculiar das classes sociais nas quais se insere a população selecionada.

rONSECA, R.M.G.S. da. Biological reproduction and social classes. Preliminary note. Rev. Esc. Enf. USP, Sào Paulo, 22(2):251-252, Aug. 1988.

\section{PRELIMINARY NOTE}

The idealistic conception of the woman health assistance programs, which ignores the social determinants of the biological reproduction, gives to the facts an explanation based on models which instead of reaching the real causes of the problems, places an ideological curtain that distorts reality and therefore offer solutions which only permit to obtain the adequate pragmatic results, without touching the actual structural causes which can unbalance the system.

* Enfermeira. Mestre em Enfermagem. Professor Assistente do Departamento de Enfermagem em Saude Coletiva da Escola de Enfermagem da USP - disciplinas Enfermagem Preventiva e Comunitária e Saude da Comunidade. 
In view of this fact we intend to develop a research with the objectives of knowing and explaining the biological reproductive profile, according to the insertion of is a specific reproductive profile, socially determined by the peculiar forms of production and consumption of each social class.

We consider that the analysis of the data through the frame of the historical and dialectic materialism, permits the scientific explanation of the biological facts, among which the biological reproduction.

The study has the purpose of obtaining subsides form the qualitative and quantitative transformation of the woman health programs on a real base, corresponding to the peculiar situation of the social classes in which is inserted the selected population.

Recebido em 16/5/88 